\title{
Mengungkap Kebungkaman Dalam Produktivitas Fiksi Pop Islami Penerbit Mizan
}

\author{
Cucum Cantini \\ Alumni Pascasarjana Ilmu Sastra UGM \\ cantini@mail.ugm.ac.id
}

\begin{abstract}
Abstrak
Penelitian ini memfokuskan kajiannya hanya terbatas pada bagaimana Penerbit Mizan menggunakan wacana Syiah yang dituduhkan atas terbitan buku pertamanya, Dialog Sunni-Syiah tahun 1983. Meski dengan justifikasi negatif tersebut, Penerbit Mizan tetap aktif dan produktif, khususnya dalam memproduksi fiksi-fiksi pop islami. Dengan menggunakan teori produksi sastra Pierre Macherey, mengenai spoken dan unspoken, ditemukan adanya proyek ideologis islamisasi dan upaya anti-western dalam fiksi-fiksi pop islaminya, dengan merealisasikannya melalui figurasi dan simbol dalam teks; hidayah, tokoh Islam, pertemuan dengan muslim, ideal dengan hijab, dominasi tokoh Arab, sejarah perlawanan Islam, dan pengedepanan latar Timur-Tengah. Dengan demikian secara tidak sadar, fiksi pop islami melunturkan citra negatif Mizan menjadi penerbit pop yang islami, sekaligus menunjukkan esksitensi kekuatan Islam. Kehadiran Mizan hadir atas antusiasme kaum intelektual pada buku-buku gagasan Islam, khususnya mengenai Revolusi Islam Iran tahun 1979. Dengan sensitivitas masa Orde Baru pada wacana revolusi, maka Penerbit Mizan ikut menjadi bagian dari citra negatif dalam Islam. Dengan semakin produktif Mizan memproduksi buku-buku pop, maka semakin luntur citra tersebut, sekaligus di dalamnya membangkitkan kekuatan Islam dalam budaya populer Indonesia.
\end{abstract}

Kata kunci: Fiksi pop islami, Penerbit Mizan, spoken dan unspoken, kebungkaman.

\begin{abstract}
This research focus on the discourse of Syiah that alleged to Mizan over the first publication of Dialog Sunni-Syiah which published at 1983. Despite of that negative justification, Mizan publisher still exist and productive, especially for producing pop-islamic fiction. By using Pierre Macherey's literary production theory, spoken and unspoken, then found a ideological islamization project and also an anti-western effort in the other pop-islamic fiction by realizing it through figuration and symbol inside the text; bidayah, islam figure, moslem gathering, ideal by wearing hijab, Arabian's figure domination, bistory of islamic resistance, and preferring middle east background. Therefore, unconsciously, pop-islamic fiction reducing the negative image of Mizan as pop-islamic publisher as well as showing the existence of islamic power. Mizan's presence appears because of the enthusiasm of intellectuals to the islamic ideas books, especially about Islam Iran Revolution at 1979. By the sensitivity of the discourse in Orde Baru era, then Mizan publisher be a part of negative image in islam. By the Mizan's productivity producing pop books then the more the image faded, simultaneously awaken islamic power in Indonesia's popular culture.
\end{abstract}

Keywords: Pop-islamic fiction, Mizan Publisher, spoken and unspoken, silences.

\section{Pendahuluan}

Kondisi kesusastraan saat ini sangat mungkin mendapat pengaruh yang begitu variatif dari menjamurnya penerbit-penerbit swasta serta pengaruh genre dalam fiksi. Genre hadir atas selera pembaca dan pada akhirnya penerbit yang terdorong menerbitkan fiksi sebagai konsumsi pembaca. Penentuan genre fiksi populer bergantung pada penonton dan penontonlah yang menjadi indikator dapat tidaknya fiksi tersebut terjual (Adi, 2011). Hal itu menunjukkan bahwa audiens menjadi penentu eksistensi sebuah genre dalam kesusastraan. Meski demikian, kondisi historis yang membuat pembaca mengkonsumsi genre da- 
lam fiksi menjadi lebih besar dari sekadar selera pembaca. Kondisi historis merupakan gambaran atas fakta di luar teks sastra kendatipun mungkin juga terekam dalam teks fiksi yang terbit. Kenyataan sosial, ekonomi, budaya, bahkan politik mampu memengaruhi kondisi termaksud: bagaimana hal tersebut memengaruhi kesusastraan yang diterbitkan oleh penerbit; bagaimana pembaca meminati genre yang sedang trend saat itu; atau bahkan bagaimana munculnya penerbit-penerbit yang mempublikasikan fiksi genre yang sedang diminati, terlepas dari dari kenyataan bahwa besar kemungkinan genre demikian sekadar mengikuti euforia pasar demi tuntutan keuntungan atau tidak. Betapapun, penerbit merupakan industri komersial yang berfokus pada profit untuk perusahaannya. Kondisi yang terakhir mengingatkan pada kelahiran banyak penerbit saat ini dalam pengertian yang positif.

Kondisi demikian lahir sebagai akibat dari dua peluang kemungkinan: pertama, meningkatnya jumlah pembaca yang membutuhkan bacaan; dan kedua, keuntungan yang besar dalam industri penerbitan belakangan ini yang menjadikan usaha penerbitan menjadi semakin menjamur. Data Depdikbud (1997) menyebutkan bahwa menjamurnya kelahiran penerbit swasta diawali sekitar tahun 50-an, sebagian besar berada di pulau Jawa dan selebihnya di Sumatera. Awalnya, motif yang diusung sangat kental berbau politis-idealis; ingin mengambil alih dominasi para penerbit Belanda yang setelah penyerahan kedaulatan di tahun 1950 masih diijinkan bertahan di Indonesia.
Pemerintah kemudian mendirikan Yayasan Lektur yang bertugas mengatur bantuan pemerintah kepada penerbit dan mengendalikan harga buku. Keberadaan yayasan ini berdampak pada akselerasi pertumbuhan dan perkembangan penerbitan nasional.

Akan tetapi, hasil akhir dari tumbuhkembang penerbit itu tidak sesuai dengan kondisi ideal yang diharapkan. Penerbitan di Indonesia memiliki menara panoptik-nya sendiri atas bukubuku yang dicetak dan diedarkan. Penerbit yang memiliki hak menerbitkan buku-bukunya dipasaran adalah Balai Pustaka, sementara penerbit swasta diberikan kesempatan menerbitkan buku-buku pelengkap asalkan atas persetujuan tim penilai. Dampaknya justru memengaruhi kelahiran-kelahiran penerbit yang menurut pemerintah saat itu adalah 'penerbit liar' yang mencetak buku-buku yang tidak layak beredar. Penerbitan buku harus melalui sensor dan persetujuan kejaksaan agung. Kesuksesan terhadap belenggu pengawasan penerbitan pemerintah Belanda melalui Balai Pustaka, telah diraih dengan kebebasan penerbit-penerbit Indonesia mendirikan penerbit yang independen dan memiliki karakternya sendiri tanpa dibendung oleh aliansi apapun di tahun 1970-an. Pada masa itu, lahir dan mati-nya penerbit merupakan hal yang lumrah, terlepas dari turut campur tangan atau tidaknya pemerintah. Kelahiran, perkembangan, ataupun kematian penerbit-penerbit menjadi sebuah fenomena yang terjadi di Yogyakarta tahun 90-an (Adhe, 2007). Pertama, kelahiran penerbit tentu merujuk pada kecendrungan kebutuhan: kebutuhan masyarakat yang membutuhkan buku. 
Masyarakat yang memerlukan bacaan adalah mereka yang cenderung akademis .

Kedua, kematian penerbit di Yogyakarta dihadapkan pada kenyataan pahit kondisi yang menekankan penerbitan terhadap dua pilihan situasi; idealisme atau kapitalisme. Pilihan tersebut menjadi sulit karena penerbitan adalah sebuah industri, kalau terlalu idealis tetapi tidak sesuai dengan selera pembacanya penerbit akan collapse. Sebaliknya, kalau terlampau kapitalis, produksinya akan cenderung sangat komersial. Itu yang membuat banyaknya penerbit, khususnya penerbit di Yogyakarta, mengalami kematian tak lama setelah dilahirkan, atau keadaan yang lebih baik dari itu adalah diakuisisi penerbit lain. Akhirnya, penerbit tersebut hidup di bawah lembaga penerbit yang lebih besar yang tidak menutup kemungkinan berbeda idealisme. Euforia merger-dimerger ini terjadi sekitar 1990 -an. Tidak hanya di Yogyakarta, tetapi juga kotakota lainnya: Jakarta dengan Kompas Gramedia Grup (KPG) yang menerbitkan novel pertamanya Saman tahun 1998 karya Ayu Utami; Laskar Pelangi tahun 2005 karya Andrea Hirata yang diterbitkan oleh Bentang Pustaka yang mengalami collapse dan kemudian diakuisisi oleh Penerbit Mizan dan berganti nama menjadi Bentang Budaya.

Salah satu kota yang memiliki penerbit kampus adalah Bandung dengan Penerbit Salman dari Institut Teknologi Bandung (ITB). Ramai kabar kemunculan penerbit-penerbit khususnya penerbit kampus terjadi di tahun 1980-an ketika banyak akademisi yang membutuhkan buku-buku filsafat dan buku umum. Saat itu, kebutuhan terhadap buku-buku religius mengalami kondisi yang cukup signifikan sehingga banyak penerbit yang berlomba-lomba mendirikan penerbit yang berasas Islam. Melihat kondisi demikian, banyak mahasiswa yang juga memiliki gagasan untuk melahirkan penerbit yang sesuai dengan idealisme mereka. Maret 1983, Haidar Bagir, Ali Abdullah, dan Zainal Abidin Shahab keluar dari penerbit kampus yang digawangi ITB dan merintis penerbit yang memiliki kebebasan untuk menerbitkan buku-buku bermutu dan pandangan maju, tetapi tetap Islami. Mereka kemudian menyulapnya sebagai media yang seimbang dalam menerbitkan buku-buku dari berbagai pemikiran filsafat. Selanjutnya, Mizan dipilih sebagai nama penerbitan mereka, yang berarti timbangan atau seimbang.

Kelahiran Mizan bukanlah pertama dan satu-satunya. Faruk dalam pengantar buku Anotasi Buku-buku Islam (1998) menyebut bahwa kelahiran buku-buku Islam tersebut merupakan unsur “Kebangkitan Islam" yang ditandai dengan melimpahnya buku-buku Islam. Sebagai penerbit yang berlandaskan Islam, Mizan memiliki idealisme terhadap buku-buku yang diterbitkannya. Dalam ranah non-fiksi, buku pertama yang diterbitkannya adalah buku Dialog Sunab-Syiah (1983) yang kemudian menjadi bestseller hingga memberi Mizan citra penerbit syiah. Sementara itu, buku fiksi diterbitkan dua tahun kemudian setelah Mizan berdiri. Karena Mizan dianggap sebagai sebuah penerbit yang berlandaskan Islam, tak bisa dipungkiri bahwa fiksi-fiksi yang diterbitkannya pun bergenre keislamaan. Seri fiksi keislaman juga menjadi ciri khas Penerbit Mizan dalam buku-buku terbi- 
tannya yang dikhususkan untuk anak-anak dan remaja. Beberapa di antaranya seperti Serial Kisab Wanita Zaman Nabi dan Para Sababat; Jalan Pintas ke Surga tahun 1986, Kaca-kaca Berdebu tahun 1987, Tebaran Cahaya Surga tahun 1994, Serial Kisab Zaman Nabi dan Para Sababat, Rabasia Seuntai Kalung tahun 1985 Wanita Berlisan Suci tahun 1989, Sayap-sayap Menuju Surga di tahun 1994.

Berdasarkan karakteristik tersebut, Mizan mampu tetap berada pada jalur idealismenya: islami, tetapi tetap berada di posisi jalur industri bisnis penerbitan sebagai penerbit buku fiksi dan non-fiksi yang bertahan hingga hampir 30 tahun lebih. Banyak penerbit lain yang lahir di era yang sama tetapi mati atau diakuisisi penerbit lain. Saat ini, Mizan telah mengakuisisi beberapa penerbit seperti Penerbit Bentang dan Noura Books untuk memperbesar perusahaannya. Fenomena ini menjadi menarik untuk dikaji karena Mizan menjadi saksi lahirmati-nya penerbitan di Indonesia, sekaligus menjadi bukti penerbit yang mampu bertahan bahkan menjadi penerbit besar dengan tetap mempertahankan idealismenya. Sejak awal berdiri hingga saat ini, Mizan telah memproduksi fiksi dan non-fiksi islami, mulai dari tema-tema keislaman periode 80-an hingga kini yang lebih mutakhir. Tema islami berada pada puncaknya di tahun 2000-an. Sebuah apresiasi yang layak diberikan kepada Penerbit Mizan atas eksistensinya dalam perkembangan kesusastraan Indonesia khususnya sastra bernuansa islami yang keberadaannya mulai diminati pembaca. Kenyataan ini tidak dapat menghapus fakta masa lalu yang menghadapkan penerbit ini dengan banyak kendala. Terlebih lagi pada masa Orde Baru yang demikian ketat.

Mizan sebagai salah satu penerbit swasta yang besar di Indonesia membawa pengaruh kuat pada produksi kesusastraan Indonesia. Hal ini menunjukkan eksistensi penerbit terhadap produk -produk yang dilahirkannya. Jika awalnya Mizan dianggap sebagai penerbit yang bisa seimbang menyuarakan tema keislaman dan tema umum, dalam perkembangannya sebagai penerbit besar, Mizan juga mampu menjadi contoh yang memiliki karakter terhadap genre-genre fiksinya. Berangkat dari pemikiran Macherey tentang kondisi di luar teks yang disampaikan; bahwa ada teks-teks yang ada dalam ketiadaannya, bersifat silence dan bungkam. Dalam produksi sastra ada makna yang implisit, yang masih terkait dengan kondisi historis produk yang diproduksinya.

\section{Kebungkaman dalam Gagasan Produksi Sas- tra Pierre Macherey}

Berbeda halnya dengan teks kanon Marxis, Macherey melihat fenomena sosial bukan sebagai intervensi dalam sederet kejadian sejarah yang spesifik, melainkan lebih interferensi teoritis yang mengemukakan kembali relasi antara teks sastra, ideologi, dan sejarah. Suatu kritik ilmiah perlu menjelaskan karya sastra dalam term struktur ideologi dimana ia menjadi bagian, bahkan dimana ideologi mengubah (struktur ideologis) ke dalam karya seninya (Eagleton, 2002). Dari ideologi inilah, Macherey melihat bahwa dalam sebuah proses produksi, ideologi berperan mengubah bentuk-bentuk estetik untuk tujuan tertentu, secara sadar maupun tidak. Produksi sastra men- 
Poetika : Jurnal Ilmu Sastra

Vol. V No. 1, Juli 2017
DOI 10.22146/poetika.25697

ISSN 2338-5383 (print) ; 2503-4642 (online) jadi sebuah alat untuk mengubah bahan mentah menjadi bahan jadi. Spoken merupakan teks maupun konteks yang hadir, diakui, dan dikatakan. Dalam hal ini, kondisi diproduksinya teks-teks dalam fiksi-fiksi pop islami Mizan merupakan sebuah teks yang disampaikan pada pembacanya. Selain itu, wacana yang disampaikan terkait produktifnya Mizan dalam menerbitkan fiksi-fiksi juga menjadi menjadi kondisi bagaimana Mizan selama ini 'membungkam' apa yang tidak dikatakannya. Gagasan Macherey mengenai sejarah memiliki kesamaan dengan kerangka pemikiran Foucalt mengenai yang sama-sama berlandas dari Nietzche. Akan tetapi, Foucalt menolak struktur sebagai bagian dari sejarah. Foucalt menolak model teologis Hegelian, di mana satu mode produksi mengalir secara dialektis dari mode produksi yang lain, dan memilih taktik kritik nietzshean melalui pengajuan perbedaan (Sarup, 2011).

Kondisi yang tak terkatakan atau unspoken memiliki tiga kriteria untuk membawa pada silences atau kebungkaman; proyek ideologis; realiasasi; dan ketidaksadaran teks. Ketiga hal tersebut yang akan menguak kebungkaman dari kondisi spoken. Proyek ideologis adalah representasi ideologis yang berhubungan dengan kondisi ideologi pada umumnya. Ideologi ini sama persis dengan bentuk ideologi pada kondisi sosial sebuah masyarakat sebagai bentuk ketidaksadaran sosial (darimana subjek berasal) kondisi sastra atau pada penulisan, bentuk naratif, karakter khas, dan bahkan situasi penulis, sejauh mana ideologi tersebut merepresentasikan profesi: audien, penerbit, diantara yang lain.
Bukanlah persoalan membuat apa yang ada bisa berbicara dengan lebih banyak kejelasan sehingga akhirnya menjadi makna teks yang lengkap/utuh, karena makna teks yang bersifat dalam dan absen hanya mengulang pemahaman diri teks yang berarti gagal menjelaskan teks dengan benar. Tugas praktik kritis yang sepenuhnya kompeten bukanlah membuat terdengar apa yang bisik-bisik semata, dan juga bukan melengkapi apa yang tak terkatakan oleh teks, melainkan menghasilkan suatu pengetahuan baru tentang teks tersebut, sesuatu yang menjelaskan kepentingan ideologis dari kebisuannya, ketidakhadirannya, kekurangkomplitannya yang menstruktur, penyajian apa yang tidak bisa dikatakan. Lebih tepatnya, kondisi yang terealisasikan merupakan sebuah 'kebenaran' yang disampaikan (Storey, 2006: 41) seperti teks-teks yang diproduksi, fiksi-fiksi yang kemudian disampaikan, yang kesemuanya adalah sebuah bentuk realisasi dari proyek ideologis yang sebelumnya telah dibahas. Karena sebuah ideologi, proyek ideologis tentulah harus disampaikan, dalam hal ini disampaikan atau dikatakan melalui teks atau karya. Dalam melihat teks, karya, atau produk, dalam perspektif 'yang tak terkatakan' akan jelas sangat berbeda dari pandangan teks sebagai sebuah makna tunggal dari pemikiran humanis, realisasi dalam hal ini akan menunjukkan bagaimana sastra dipakai sebagai sebuah alat ideologis.

Keabsenan mendasari perkataan sebuah karya, silences kemudian yang membentuk semua perkataan itu (Macherey, 1966: 85). Silence inilah yang pada gilirannya akan selalu ada (eksis), bertahan (survive), dan akan muncul (dimunculkan 
kembali) di waktu yang tepat. Bagi Macherey kebungkaman tidak dapat dihilangkan, ada dan memiliki banyak makna yang menimbulkan beragam bentuk, manifestasi sebuah karya, membongkar yang tidak bisa dikatakan. Kebungkaman inilah yang kemudian menghidupkan karya itu sendiri. Macherey menggambarkan antara ujaran/perkataan dan kebungkaman ini dengan figure dan ground. Figure atau figurasi adalah simbol dari sebuah ujaran/ perkataan, sementara ground diidentifikasikan dengan silence, kebungkaman, atau absensinya, ini lebih kepada sebuah bentuk yang implisit dan eksplisit. Kebungkaman tidak mencerminkan kontradiksi historis, sebaliknya hal tersebut membangkitkan, menghadirkan, dan menampilkan kontradiksi-kontradiksi historis itu, yang bukan memberikan sebuah pengetahuan ilmiah, tentang ideologi, tetapi sebuah kesadaran di hadapan pertanyaan-pertanyaan yang tidak bisa dijawabnya, gagal melakukan apa yang diandaikan dilakukan ideologi. Ideologi sendiri ada justru untuk menghapuskan semua jejak kontradiksi (Macherey, 1966). Maka dari itu semua ketidaksadaran teks terhadap kehadirannya mampu ditampilkan.

\section{Yang Terkatakan dan Tak Terkatakan da- lam Produksi Fiksi Pop Islami Mizan}

Islamisasi telah menjadi sastu-satunya ciri paling mencolok yang mewarnai dekade pertama Indonesia sesudah Orde Baru (19661998), sekalipun islamisasi memiliki sejarah lebih panjang dengan dengan kebangkitan dramatis Islam dalam kehidupan publik pada dekade 1990-an, nyaris satu dekade sebelum ke- jatuhan pemerintah Orde Baru (Heryanto, 2015: 37). Kehadiran fiksi-fiksi pop islami dewasa ini merupakan sebuah bentuk manifestasi antara bentuk-bentuk Islam yang menunjukkan budaya Islam Arab dengan unsur-unsur budaya Islam Indonesia dari mulai pada era akhir 90-an. Perkembangan fiksi pop islami hadir pada tahun 2000-an ketika Mizan merombak dirinya menjadi lebih segmentatif, yakni melahirkan divisi yang ditujukan kepada anak-anak dan remaja dengan labelnya Dar! Mizan. Dar! Mizan atau Divisi Anak dan Remaja ini kemudian memiliki lininya berupa Sobat Bocah Muslim, Mio, Sahabat Remaja Muslim, Mizan Komik Indonesia, Main!, dan Pelangiku.

Membanjirinya komik dan novel-novel remaja inpor ternyata tak cukup kuat membendung kreativitas para insan penerbitan Islam ini. Demikian pula, minimnya sumber-sumber terjemahan bagi buku-buku anak dan remaja yang mampu membawakan pesan-pesan Islam ini justru mendorong mereka untuk melahirkan karyakarya orisinal dari dalam negeri (local genius). Maka, beberapa tahun belakangan ini masyarakat menyaksikan, betapa di tengah manga dan novel-novel Barat yang tak jarang membawa bersamanya unsur-unsur yang bukan hanya asing, melainkan menabrak apa-apa yang diyakini oleh banyak bagian masyarakat kita-terselip seri yag tak biasa. Ada "Seri Cerita Pesantren", "Komik Ibadah", "Komik Lucu", "Seri Cerita Balita", "Seri Kukuruyuk", "Seri Cerita Nabiku", "NORI" (Novel Remaja Islami), "NOMIK" (Novel Komik), bahkan berbagai alat peraga yang mengusung misi pendidikan Islam. Maka terbesit harapan besar bahwa derasnya pengaruh budaya permisivistik-termasuk pornografi, pergaulan, dan seks bebasmendapatkan tantangan yang setimpal. Melihat potensinya untuk menjadi semacam wahana counter culture yang positif ini, maka kehadiran karya-karya literer bernuansa Islam untuk anak dan remaja ini pun 
layak disebut sebagai Revolusi Ketiga.

(Haidar Bagir, 2003)

Meskipun dengan kondisi demikian, Mizan melakukan negosiasi antara budaya islam dengan gaya cerita komik dan fiksi, dengan membuat komik dan fiksi islami. Dengn demikian, Mizan tidak bisa dikatakan bahwa dirinya melakukan sebuah perlawanan akan tetapi sebuah bentuk manuvernya yang lebih cenderung hibrid, yakni tetap menggunakan gaya penulisan dan ilustrasi bergaya barat (komik dan fiksi), tetapi mengkombinasikannya dengan teks bernuansa islami. Inilah kemudian yang menjadikan Mizan memiliki karakter sebagai sebuah industri yang mampu bertahan dengan melakukan sebuah proyek ideologis: bahwa pembaca harus waspada terhadap invasi asing dan harus memilih kultur Indonesia yakni Indonesia yang islami. Dalam fiksi pop islami anak terbitan Mizan, kisah-kisah princess diterbitkan melalui formulasi antara kisah-kisah putri dan unsur-unsur islami; hijab, cerita islami, atau pun asmaul husna. Formula-formula pop anak yang menjadi ciri khas ala barat inilah yang dinegosiasikan oleh Mizan. Ancaman kehadiran fiksi asing yang masuk melalui fiksi-fiksi pop dan komik, secara tak langsung dan tak sadar dirinya (Mizan) juga melakukan antiwestern ini dengan menggunakannya; menerbitkan fiksi pop dan komik gaya barat.

Masyarakat di Indonesia pun sempat menyebut Mizan sebagai penerbit Syiah terkemuka di Indonesia, sebelum kemudian menganggapnya sama seperti buku-buku umum lainnya sekarang ini (Asy Syariah, 2013). Sebagai penerbit profesional, Mizan harus melaksanakan strateginya, yakni dengan banyak memproduksi buku-buku beragam aliran, serta buku populer lainnya, termasuk diantaranya adalah fiksi pop islami. Dengan fiksi-fiksi pop islami inilah, Mizan kemudian bisa melunturkan citra Syiahnya. Jika melihat dari persentase jumlah fiksi-fiksi islami yang diterbitkan oleh Mizan, sebanyak 280 eksemplar (1985-2015), semakin lama Mizan semakin produktif menerbitkan fiksi-fiksi pop sehingga hal ini secara perlahan melunturkan citra madzhab Mizan menjadi penerbit bermadzhab pop. Meskipun tidak bisa dipungkiri citra Syiah ini merupakan sebuah jalan untuk Mizan menjadi populer dan dikenal meski bisa dikatakan citra ini negatif. Mizan dengan menejerialnya tersebut melakukan sebuah manuver yang tepat dengan menerbitkan fiksifiksi pop, khususnya fiksi pop islami, yang masih satu jalur dengan idealisme yang dibangunnya sejak awal.

Melalui fiksi pop islami, Mizan merealisasikan proyek ideologisnya. Dengan menggunakan unsur-unsur dalam fiksi, Mizan kemudian memfigurasi dan men-simbolkan ke dalam teks-teks proyek ideologisnya tersebut. Pertama, dalam plot yang memasukan formulasi-formulasi seperti hidayah, peristiwa Islam (sejarah), dan pertemuan dengan tokoh muslim.

"Siapa yang bingung!" Judith jengkel bukan main. "Aku percaya Tuhan itu ada! Yang aku bingung gimana caranya berhubungan sama Dia."

"Makanya kita harus cari sampai ketemu." Celetuk Barbara. "Aku juga belum ketemu, ini lagi nyari-nyari. Apa salahnya mempelajari Islam selagi ada temen yang tahu, meski sedikit. Aku gak mau sampe tua nanti masih bingung terus, pas dikubur nggak 
Udara Jakarta siang itu, tengah panaspanasnya. Di selatan Jakarta, tepat saat bubar anak sekolah, di sebuah SMA yang cukup megah, ratusan siswa keluar bersamaan.

Jalan di depan sekolah itu serentak macet. Mobil dan motor antre keluar dari gedung sekolah it. Belum lagi mobil penjemput yang tidak bisa masuk area parkir. Mereka berhenti di badan jalan dan mempersempit ruang kendaraan yang lalu lalang.

(Avianty, 2009: 25)

Kami mengitari Ka'bah dalam kemewahan cahaya langit Makkah dan lampulampu eksotis Masjidilharam. Jauh lebih indah daripada menikmati malam di Merlion dan Esplanade (Singapura), Times Square (New York), atau bermalam tahun baru sambil menonton pesta kembang api di Champ's D'Elysee (Paris). Aku jatuh cinta dengan kesempurnaan malam di Makkah ini.

(Avianty, 2009: 117)

Formulasi-formulasi tersebut, memiliki fungsi terhadap Islam sekaligus Mizan. Dari penjelasan berdasarkan analisis plot, latar, dan karakter yang terdapat dalam fiksi-fiksi pop islami Mizan, menunjukkan figurasi yang merepresentasikan Islam secara berkelanjutan. Islam diwakili oleh simbol-simbol yang secara kuat berada pada tataran semiotik. Dari formulasiformulasi tersebut, Islam yang dan Mizan kemudian terepresentasikan, sehingga secara perlahan menunjukkan kekuatan eksitensi Islam dan Mizan secara khusus.

Meminjam istilah Storey (2006) bahwa kondisi yang terealisasikan merupakan ‘kebenaran’ yang dijanjikan. Melalui teks-teks fiksi pop islami, secara berkelanjutan, Mizan memproduksi proyek ideologinya; pertama, meyakinkan pembaca bahwa gaya kebarat- baratan tersebut haruslah disingkirkan, dilawan, serta digantikan dengan kultur Islam melalui tindak figurasi ketimuran, atau dalam hal ini Arab sebagai kultur utama Islam. Mizan melalui tindak realisasi figurasi ini memberikan sebuah pehamanan baru yang secara halus, berkelanjutan, dan terus-menerus diproduksi melalui produkproduknya, fiksi pop islami. Melalui fiksi pop islami inilah, Mizan mampu menyampaikan proyek ideologinya dengan mudah karena melalui fiksifiksi pop, pembaca mampu membaca apa yang hendak disampaikan oleh Mizan. Dalam produktivitas Mizan, kehadiran fiksi pop islami mampu menanjak pada tingkat tertinggi di periode 2000 2005 dengan angka 125 judul buku hanya dalam kurun waktu lima tahun.

Fenomena yang membangkitkan popularitas Islam dalam budaya pop tidak hanya sebatas apa yang nampak. Kendatipun ketidakhadiran tersebut mampu dibongkar melalui proyek ideologis dan realisasinya. Ada semacam relasi antara popularitas Islam dan popularitas Mizan, keduanya sama-sama 'bangkit' dan memuncak. Bagi Macherey semakin teks berbicara, semakin ada yang disembunyikannya. Dan hal tersebut berpijak dari kondisi historis teks tersebut hadir. Jauh dari periode kebangkitan Islam dan Mizan, ada kondisi yang tidak disadari teks bahwa kehadirannya (spoken) membangkitkan kondisi unspoken. Segala wacana mengenai Islam dan fiksi pop islami Mizan berangkat jauh dari Revolusi Islam Iran tahun 1979.

Revolusi Islam Iran merupakan revolusi yang berdasarkan pada kejatuhan rejim atas ketidakpuasan rakyat Iran atas kepemimpinan Shah 
Udara Jakarta siang itu, tengah panaspanasnya. Di selatan Jakarta, tepat saat bubar anak sekolah, di sebuah SMA yang cukup megah, ratusan siswa keluar bersamaan.

Jalan di depan sekolah itu serentak macet. Mobil dan motor antre keluar dari gedung sekolah it. Belum lagi mobil penjemput yang tidak bisa masuk area parkir. Mereka berhenti di badan jalan dan mempersempit ruang kendaraan yang lalu lalang.

(Avianty, 2009: 25)

Kami mengitari Ka'bah dalam kemewahan cahaya langit Makkah dan lampulampu eksotis Masjidilharam. Jauh lebih indah daripada menikmati malam di Merlion dan Esplanade (Singapura), Times Square (New York), atau bermalam tahun baru sambil menonton pesta kembang api di Champ's D'Elysee (Paris). Aku jatuh cinta dengan kesempurnaan malam di Makkah ini.

(Avianty, 2009: 117)

Formulasi-formulasi tersebut, memiliki fungsi terhadap Islam sekaligus Mizan. Dari penjelasan berdasarkan analisis plot, latar, dan karakter yang terdapat dalam fiksi-fiksi pop islami Mizan, menunjukkan figurasi yang merepresentasikan Islam secara berkelanjutan. Islam diwakili oleh simbol-simbol yang secara kuat berada pada tataran semiotik. Dari formulasiformulasi tersebut, Islam yang dan Mizan kemudian terepresentasikan, sehingga secara perlahan menunjukkan kekuatan eksitensi Islam dan Mizan secara khusus.

Meminjam istilah Storey (2006) bahwa kondisi yang terealisasikan merupakan ‘kebenaran’ yang dijanjikan. Melalui teks-teks fiksi pop islami, secara berkelanjutan, Mizan memproduksi proyek ideologinya; pertama, meyakinkan pembaca bahwa gaya kebarat- baratan tersebut haruslah disingkirkan, dilawan, serta digantikan dengan kultur Islam melalui tindak figurasi ketimuran, atau dalam hal ini Arab sebagai kultur utama Islam. Mizan melalui tindak realisasi figurasi ini memberikan sebuah pehamanan baru yang secara halus, berkelanjutan, dan terus-menerus diproduksi melalui produkproduknya, fiksi pop islami. Melalui fiksi pop islami inilah, Mizan mampu menyampaikan proyek ideologinya dengan mudah karena melalui fiksifiksi pop, pembaca mampu membaca apa yang hendak disampaikan oleh Mizan. Dalam produktivitas Mizan, kehadiran fiksi pop islami mampu menanjak pada tingkat tertinggi di periode 2000 2005 dengan angka 125 judul buku hanya dalam kurun waktu lima tahun.

Fenomena yang membangkitkan popularitas Islam dalam budaya pop tidak hanya sebatas apa yang nampak. Kendatipun ketidakhadiran tersebut mampu dibongkar melalui proyek ideologis dan realisasinya. Ada semacam relasi antara popularitas Islam dan popularitas Mizan, keduanya sama-sama 'bangkit' dan memuncak. Bagi Macherey semakin teks berbicara, semakin ada yang disembunyikannya. Dan hal tersebut berpijak dari kondisi historis teks tersebut hadir. Jauh dari periode kebangkitan Islam dan Mizan, ada kondisi yang tidak disadari teks bahwa kehadirannya (spoken) membangkitkan kondisi unspoken. Segala wacana mengenai Islam dan fiksi pop islami Mizan berangkat jauh dari Revolusi Islam Iran tahun 1979.

Revolusi Islam Iran merupakan revolusi yang berdasarkan pada kejatuhan rejim atas ketidakpuasan rakyat Iran atas kepemimpinan Shah 
Pahlevi yang terlalu diintervensi oleh Amerika. Istilah westernisasi menjadi momok masyarakat yang kemudian mereka anti terhadap segala bentuk westernisasi tersebut. Ayatullah Khomenei yang telah diasingkan selama bertahun-tahun itu memimpin sebuah revolusi besar dalam sejarah dunia, dengan usia yang menginjak 80 tahun, dirinya kemudian mengibarkan bendera Islam Iran dan meruntuhkan rejim Pahlevi yang telah bertahan lama di Iran. Esposito (1990) mengatakan bahwa Revolusi Islam Iran merupakan kebangkitan Islam dunia di era kontemporer.

Keruntuhan Pahlevi dengan kekuatan negara-negara barat, merupakan sebuah sejarah besar, terutama bagi umat Islam. Kehadiran Khomeni tentu didukung oleh sebuah kekuatan besar yang bisa meruntuhkan sebuah dinasti yang telah berkuasa dari tahun 1921. Kekuatan besar yang dimiliki Khomeni nyatanya lebih besar dari sekedar kekuatan militer maupun dukungan negara asing, ataupun teror-teror kematian kejam yang dihukumkan terhadap warga yang memberontak. Ideologi Syiah telah meruntuhkan segala kekuatan yang selama ini mengekang Iran. Nasr (1981) berpendapat bahwa baik Sunni maupun Syiah merupakan penafsiran ortodoks atas Islam yang terkandung di dalam Islam sejak awal untuk menyatukan orang-orang yang memiliki keadaan psikologis yang berbeda. Keduanya merupakan bagian integral dari ortodoksi sejak awal. Syiah bukanlah heterodoksi ataupun sekte, meskipun dalam kalangan Syiah terdapat kelompok-kelompok yang telah menyimpang dari ortodoksi dan betul- betul merupakan sekte. Dari pernyataan tersebut, dapat dilihat bahwa perkembangan pemahaman terhadap sebuah keyakinan dapat dianggap sebuah ideologi yang dipegang teguh pada setiap individu maupun kelompok.

Revolusi Iran telah mampu bersanding dengan dua revolusi besar dunia; Revolusi Prancis dan Revolusi Bolshevik. Dan Revolusi Iran merupakan sebuah kebangkitan bagi Islam di era kontemporer. Bagaimanapun, revolusi ini membawa panji Islam ke dalam sejarah dunia yang mampu menjadikan Islam sebagai salah satu sekutu Amerika setelah Rusia. Khomeini telah membangun persepsi kekuatan Islam yang fantastis dengan mendukung gagasan Ikhwanul Muslimin (Mesir) dan Maulana Al Mahdudi (India) yang anti-Amerika. Kaum intelektual kemudian berbondong-bondong mencari tahu dan berharap akan sebuah revolusi yang sama pada negara-negara mereka (Sofjan, 2011). Meskipun tidak dipungkiri, hal ini sulit diaplikasikan pada semua negara ber-mayoritas muslim sekalipun. Gagasan-gagasan pemikiran Khomeini, Syariati, serta Murthada Muthahari menjadi incaran kaum akademisi untuk dikonsumsi, dan sebagian lagi langsung mempelajarinya di Qum, Iran.

Pemahaman akan revolusi yang kontekstual ini yang menjadikan para intelektual mencari informasi melalui teks-teks buku. Dan tak bisa dipungkiri, ketika kebutuhan akan bacaan yang meningkat, banyak penerbitan yang banting stir atau bahkan membangun media penerbitan yang mampu memberikan keinginan konsumennya. Mizan tercatat sebagai salah satu penerbit yang lahir di era Orde Baru, dan menerbitkan bukunya ber- 
judul Dialog Sunni-Syiah di tahun 1983. Buku yang diterjemahkan oleh ayah Haidar Bagir, selaku salah satu pelopor pendiri Mizan ini kemudian membuat penerbit Bandung ini ditengarai sebagai salah satu penerbit yang menyebarluaskan ajaran Syiah di Indonesia (Sofjan, 2011: xxiii). Sebab ketertarikan terhadap fenomena Revolusi Islam Iran tentu berangkat dari kekangan otoriter yang dialami oleh masyarakat Indonesia pada saat itu. Terlebih menurut Sofjan (2011) Soeharto sangat berhati-hati terhadap Iran dan menganggap paham Syiah berikut ideologi revolusionernya berpotensi untuk menngoyahkan status quo.

Bahkan Majelis Ulama Indonesia (MUI) pernah mengeluarkan rekomendasi dari Rapat Kerja Nasional pada tanggal 7 Maret 1984 mengenai himbauan kepada "Umat Islam Indonesia yang berpaham Abl as-sunnah wa al-jama'ah agar meningkatkan kewaspadaan terhadap kemungkinan masuknya paham yang didasarkan atas ajaran Syiah". Sekali pun alasan formal atas 'kewaspadaan' ini didasari oleh argumentasiargumentasi teologis, tidak mustahil bahwa di balik itu ada landasan politis yang dikedepankan karena kekhawatiran terhadap spoiller effect dari Revolusi Islam Iran atau pun kepemimpinan Khomeini terhadap rezim Orde Baru yang opresif dalam menekan segala bentuk kekuatan dan aktivisme Islam yang berpotensi untuk menentang kekuasaan otoriternya. Maka oleh sebab itu, di masa-masa benturan ideologi tersebut, sangat sensitif untuk terjadi segala bentuk perselisihan dan penindasan pada kaum Syiah.

Akan tetapi, kekuatan Islam ini hadir dalam fenomena politik melalui kelahiran partaipartai Islam dalam era transisi Orde baru menuju masa reformasi. Partai-partai Islam ini kemudian menjadi salah satu bentuk sumbangsih terhadap kajian-kajian bernuansa Islami melalui buku-buku Islam yang mulai memiliki kebebasannya untuk beredar luas. Hingga pada akhirnya Islam menemukan identitasnya, sebagai sebuah bagian dari identitas Indonesia yang masuk melalui sendi politik, sosial-budaya, hingga ekonomi. Pada masa ini, akan mudah ditemui, bagaimana Islam telah menjadi bagian dari masyarakat, semua produk bernapaskan Islam seolah hal yang wajib dikonsumsi, akan tetapi sekaligus menjadi konsumsi pop dengan menjamurnya produk-produk yang dibuat masal, dan dianggap sebagai bagian budaya Indonesia.

Euforia fiksi-fiksi pop islami saat ini, seperti yang sudah dibahas, memiliki sejarah panjang sampai bisa—pada akhirnya—diterima sebagai bagian dari kultur Indonesia. Kehadiran fiksi pop islami ini telah menggeser fenomena fiksi-fiksi pop impor, meskipun kehadiran fiksi pop islami ini bisa dianggap baru, tetapi fenomenanya booming seriring dengan populernya gaya Islam dalam beragam aspek di Indonesia. Sejak periode awalnya, Mizan menerbitkan fiksi-fiksi hikayat hingga terjadi garadasi atau formula baru berupa fiksi pop islami saat ini, telah membuktikan Mizan merupakan penerbit produktif yang telah merealisasikan janjinya sesuai dengan proyek ideologis yang diusungnya.

Ketakutan terhadap ancaman invasi westernisasi yang menyerang budaya Indonesia, telah digantikan dengan gaya islamisasi dalam bidang 
kesusastraan. Dengan menegosiasikan antara fiksi bernuansa islami dengan metode penulisan gaya pop barat, Mizan terbukti telah melunturkan citra Syiah yang selama ini telah membebaninya, dan menggantikan 'mazhab' tersebut dengan citra penerbit pop. Hal itu tidak akan mungkin berjalan semestinya jika tidak didukung manjemen dan strategi perluasan divisi yang dilakukannya. Secara tidak sadar, figurasi -figurasi atas nama simbol-simbol Islam dalam fiksi-fiksi pop islami-nya telah menjalankan proyek ideologis tersebut.

\section{Kesimpulan}

Sebagai sebuah penerbitan yang telah bertahan lebih dari 30 tahun, Mizan mengalami kendala dari mulai kelahirannya di tahun 1983. Sebagai sebuah bagian dari gerakan literasi, Penerbit Mizan yang mendeklarasikan dirinya untuk menjadi penerbit yang berlandaskan Islam yang seimbang. Menerbitkan buku-buku dengan tetap mempertimbangkan kualitasnya. Islam sendiri mengalami banyak kendala sebagai sebuah agama yang banyak dibelenggu di masa Orde Baru, maka dengan runtuhnya rezim tersebut Islam menemukan kebangkitannya.

Penerbit Mizan lahir dari sebuah upaya menerbitkan buku-buku Islam yang di era 80-an banyak diminati oleh akademisi yang mencari informasi mengenai Revolusi Islam Iran. Maka buku pertama yang diterbitkannya adalah Dialog Sunnah-Syiah yang merupakan jembatan bagi pembaca untuk melihat gagasan keilmuan yang menjadi pro-kontra atas ideologi apa yang menjadi penggerak umat muslim di Iran di masa tersebut. Dengan demikian citra Syiah melekat pa- da Mizan atas dasar sensitivitas masa Orde Baru yang merasakan ancaman dari kehadiran Islam dan revolusi.

Citra tersebut, meskipun sulit dihilangkan, tidak membuat Mizan berhenti produktif. Kebebasan Islam untuk masuk ke dalam kesusastraan digunakan sebaik-baiknya oleh Mizan untuk menerbitkan fiksi-fiksi bernuansa Islam. Dengan maraknya Islam yang menyeruak ke dalam budaya pop, maka unsur-unsur keislaman dalam sastra pop masuk ke dalam kriteria genre fiksi pop islami. Di dalamnya memuat unsur-unsur kekuatan Islam melalui islamisasinya. Alih-alih melawan westernisasi, Mizan menggunakan mode sastra anak princess untuk mempopulerkan sastra islami anak-anak dengan menggabungkan tema putri kerajaan (Inggris) dengan simbol-simbol Islam; putri dengan nama Islam yang berhijab. Tetapi dengan produktivitasnya menerbitkan fiksi-fiksi pop islami, Mizan sekaligus melunturkan citra Syiahnya dengan mendeklarasikan dirinya sebagai penerbit pop islami. Dengan proyek ideologis tersebut, Mizan merealisasikannya melalui figurasi dan simbol-simbol Islam yang menunjukkan kekuatan Islam melalui gaya plot, tokoh, dan latar.

Dengan demikian, kehadiran fiksi pop Islami secara tidak sadar telah melunturkan imej yang melekat pada Mizan. Imej atau citra Syiah yang menjadi wacana tersebut berawal dari kehausan para akademisi terhadap buku-buku mengenai Iran dan revolusinya. Iran yang merupakan negara Islam dengan ideologi Syiah tersebut mampu mencapai revolusi di tahun 1979. Sensitivitas Orde Baru terhadap revolusi dan ancaman terhadap negara telah membelenggu Islam dan segala ga- 
gasannya masuk ke Indonesia. Namun dengan runtuhnya Orde Baru di tahun 1998, Islam menemukan kebebasan, kebangkitan, serta popularitasnya. Mizan dalam hal ini diuntungkan dengan gagasan Islam dan manajemennya yang mapan di usianya yang ke tiga puluh tahun.

\section{Daftar Pustaka}

Adhe. 2007. Kamar Kerja Penerbit Jogja (19982007). Yogyakarta: KPJ.

Adi, Ida Rochani. 2011. Fiksi Populer: Teori dan Metode Kajian. Yogyakarta: Pustaka Pelajar.

Avianty, Ifa. 2009. Alena: Selubung Cinta di Muzdalifah. Bandung: Mizan.

Depdikbud. 1993. Data Penerbit Indonesia. Jakarta: Departemen Pendidikan dan Kebudayaan.

Depdikbud. 1997. Penerbit dan Toko Buku di Indonesia. Jakarta: Departemen Pendidikan dan Kebudayaan.

Eagleton, Terry. 2002. Marxisme dan Kritik Sastra. Yogyakarta: Sumbu Yogyakarta.

Effendi, Tyas. 2009. Izinkan Aku Bersujud. Bandung: Mizan.

Escarpit, Robert. 2008. Sosiologi Sastra. Jakarta: Yayasan Obor Indonesia.

Esposito, John. 1990. Islam dan Politik. Jakarta: Bulan Bintang.

Heryanto, Ariel. 2015. Identitas dan Kenikmatan: Politik Budaya Layar Indonesia. Jakarta: KPG.

Macherey, Pierre. 1966. A Theory of Literary Production. London: Routledge \& Kegan Paul ltd.

Mizan. 2003. Mosaik. Bandung: Mizan.
Ramly, Andi Muawiyah. 2000. Peta Pemikiran Karl Marx (Materialisme Dialektis dan Materialisme Historis). Yogyakarta: LKis.

Sarup, Madan. 2011. Panduan Pengantar untuk Memahami Postrukturalisme \& Posmodernisme. Yogyakarta: Jalasutra.

Sofjan, Dicky. 2013. Sejarah \& Budaya Syiah di Asia Tenggara. Yogyakarta: Sekolah Pascasarjana, Universitas Gadjah Mada.

Storey, John. 1998. Cultural Theory and Popular Culture. Athens: University of Georgia Press. 2006. Pengantar Komprehensif Teori dan Metode Culural Studies dan Kajian Budaya Pop. Bandung \& Yogyakarta: Jalasutra.

Suaedy, Ahmad. 1998. Anotasi 200 Buku Islam Karya Muslim Indonesia. Yogyakarta: Dian Interfidei.

Sulaeman, Otong. 2010. Dari Jendela Hauzah. Bandung: Mizan.

Zayar. 2002. Revolusi Iran: Sejarah dan Hari Depannya. Yogyakarta: Sumbu.

Yudisia, Sinta. 2007. Lafaz Cinta. Bandung: Mizan. Assyariah."Gelombang Masuknya Syiah ke Indonesia", http://asysyariah.com/syiah-diindonesia. Diakses pada tanggal 3 Januari 2015. Pukul 23.00 WIB. 